\title{
Guidelines for Freshwater Pond Management in Bangladesh
}

\author{
Ibrahim Rashid \\ Assistant Professor \\ Department of Fisheries Biology and Aquatic Environment \\ Bangabandhu Sheikh Mujibur Rahman Agricultural University, Gazipur-1706, Bangladesh \\ E-mail: ibrahim@bsmrau.edu.bd \\ Mahmudul Hasan Mithun \\ MS Student \\ Department of Fisheries Biology and Aquatic Environment \\ Bangabandhu Sheikh Mujibur Rahman Agricultural University, Gazipur-1706, Bangladesh \\ E-mail: mithun3622bsmrau@gmail.com
}

Received: April 29, 2020

doi: I0.4628I/bjmsr.v2i2.645
Accepted: May 30, 2020

Online Published: June 28, 2020

URL: https://doi.org/I0.4628I/bjmsr.v2i2.645

\begin{abstract}
The pond aquaculture sector in Bangladesh expands rapidly. Total fish production from pond aquaculture increasing day by day. Bangladesh ranks fifth in aquaculture production and becomes fourth in the tilapia production in the world. Total fish production in Bangladesh was about 4.27 million MT in 2017-I8 fiscal years and the pond aquaculture production was about I.9 million MT which contributes about $44.43 \%$ of the total fisheries production in 2017-18. That means pond aquaculture contributes a lot in Bangladesh fisheries sectors. For getting proper outcome from the pond aquaculture some basic guidelines should be followed during pre-stocking, stocking, and post stocking management of freshwater pond. Firstly, pond should be prepared properly before stocking of fish seed like aquatic weeds and predators should be eradicated with properly constructed the pond bottom and dike and then liming and fertilization should be done for making a better culture environment for fish. Good quality fish seed should be sock to the pond and feeding should be done properly. Periodic sampling for examining the proper growth and any disease infestation occurs should be done. Liming and fertilization should be done after stocking of fish seed if needed. Harvesting and marketing of fish should be done by considering some factors to get good profit.
\end{abstract}

Keywords: Pond Aquaculture, Present Status, Pre-Stocking, Stocking, Post Stocking, Management, Bangladesh.

\section{Introduction}

Bangladesh is riverine and located in South Asia between 20³4' to $26^{\circ} 38^{\prime} \mathrm{N}$ latitude and $88^{\circ} 0 \mathrm{I}^{\prime}$ to $92^{\circ} 42^{\prime}$ E longitude with an area of 147570 sq. km (Sunny et al., 2020a). According to The World Bank report (2018) the total population of Bangladesh is about I6I.4 million. Inland open water captures fisheries production Bangladesh ranks third and fifth in aquaculture production in the world (Sunny et al., 2020b). At present, Bangladesh ranks 4th in the world in tilapia production and 3rd in Asia (DoF, 2018). Fisheries sector contributing 3.57\% to the country's Gross Domestic Product (GDP) and contributing to the agricultural GDP, almost one-fourth (25.30\%) (DoF, 2018). Fisheries sectors play an important role in fulfilling the demand for animal protein and socio-economic improvement of the country. More than II\% of the total population of Bangladesh is involved in this sector in full time and part-time basis for their livings (FAO, 2018). About 60\% of animal protein consumption comes from fish (DoF, 20I8). Inland open water and inland closed water covers approximately 3.92 and .79 million ha respectively but the total fisheries production was 1.2 and 2.4 million metric tons (MT) respectively which indicates inland open water body is about 4.9 times more than the inland closed water body but the total culture fisheries production is double than the inland capture fisheries production (DoF, 20I8). In I983-84, inland capture and culture fisheries shared to the total fish production about 62.59 and I5.53 percent, respectively; whereas in 20I7-I8, inland capture and culture 
fisheries share to the total fish production were 28.45 and 56.24 percent, respectively (DoF, 2018). Pond aquaculture contributes about I.9 million MT (44.43\%) in the fisheries sector in 2017-I8 which is almost half of the total fisheries production. In 2017-I8 fiscal years Bangladesh exported around 4309.94 crore taka and shrimp aquaculture is notable in export sector as it is a second export-oriented product in Bangladesh (DoF, 2018). That means pond aquaculture contributes a lot to our economy and fulfills the nutritional demand of our extended population. Day by day pond aquaculture sector expands in our country. Now a day's different scientific technology is applied in pond aquaculture for the better fish growth and production. Without a scientific approach, it is difficult to expand aquaculture and increase fish production. In this paper, scientific guidelines of freshwater pond management are stated by which a fish farmer can be scientifically practiced the pond aquaculture.

\section{Present Status of the Fisheries Sector in Bangladesh}

The fisheries sector in Bangladesh is broadly divided into three sub-sectors: inland capture, inland culture, and marine fisheries (DoF, 2018). The inland fishery is further divided into two subsectors: the inland capture fishery and inland culture fishery. The total fish production in 2017-I8 was about 427664I MT, on which total inland capture fisheries production was I2I6539 MT, total inland culture fisheries production was 2405415 MT and the total marine fish production was about 654687 MT (Figure OI) which indicates inland culture fisheries production is about double then the inland capture fisheries and 3.5 times than the marine fisheries production (DoF, 2018).

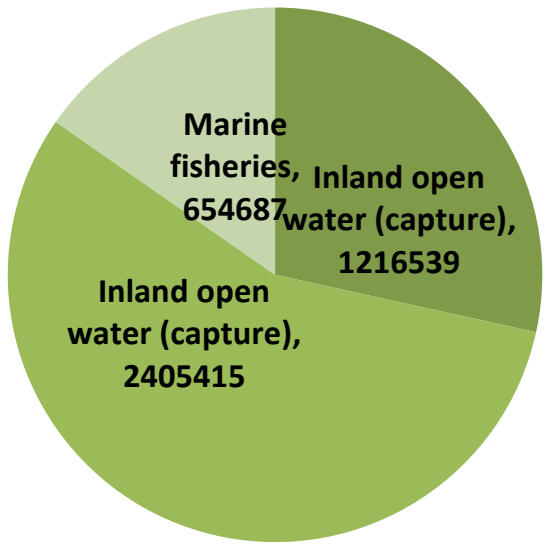

Figure I. Bangladesh fisheries production (MT) 2017-2018 (DoF, 2018).

The total inland fisheries production from both capture and culture is about 3621954 MT on which pond aquaculture itself contributes about 1900298 MT which is about $44.43 \%$ of the total fisheries production in 2017-2018 of Bangladesh (DoF, 2018). Among different sectors of inland culture fisheries production, pond aquaculture contributes several folds more than the other sectors. The shrimp aquaculture contributes about $254367 \mathrm{MT}$ and then the seasonal culture contributes about 2I6353 MT in inland culture fisheries production and the contribution of other cultural sectors are so negligible (Figure 2).

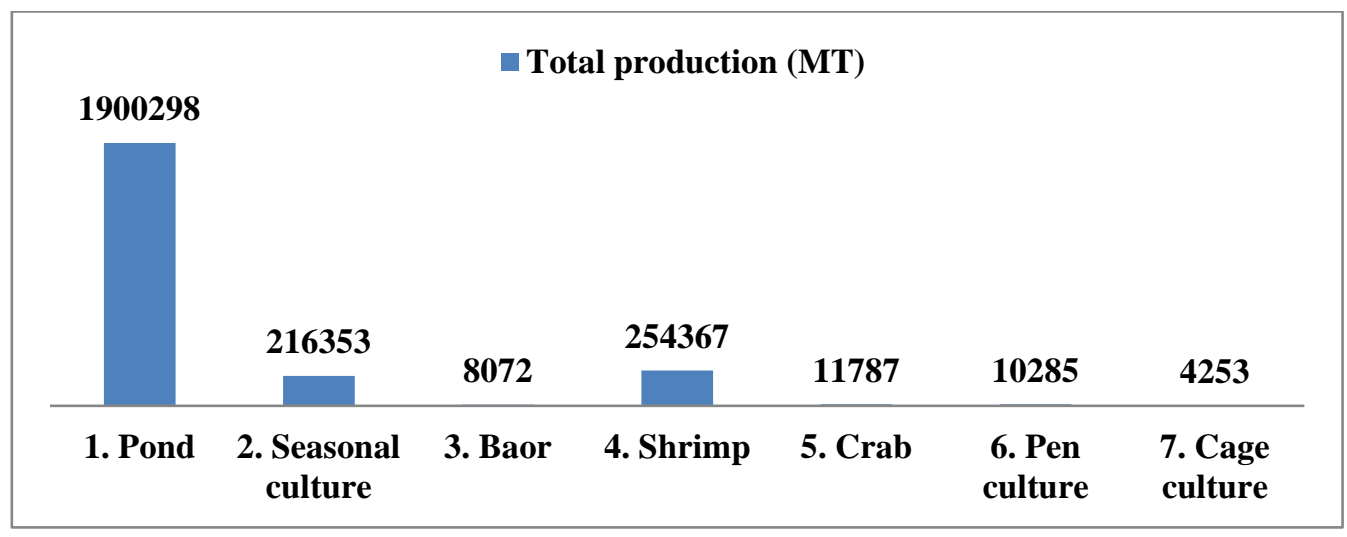

Figure 2. Sector-wise inland culture fisheries production in 2017-I8 (DoF, 20I8). 


\section{Freshwater Pond Management}

For culturing fish in the pond, there are usually three stages of management:

- Pre stocking management

- Stocking management

- Post- stocking management

\section{I Pre-Stocking Management}

As pre-stocking management practice, the ponds should be dewatered completely and therefore the bottom should be sun-dried so that the pond is often cleared off the undesirable weeds, predatory and weed fishes also as insects and crustaceans. When complete draining isn't possible, the following steps should be followed.

\section{I.I Removal of Aquatic Weeds and Construction of The Pond Dike and Pond Bottom}

Balanced biomass of submerged vegetation and algal growth is requisite for the ecosystem of a composite culture pond. Excessive infestation is harmful. Clearance of weeds is the primary consideration just in case of the reclamation of old ponds for fish culture. Water hyacinth, ipomoea, sedges, rushes, lotus, lilies, italia, Vallisneria, pistia, Salvinia, other aquatic grass, and planktonic and filamentous algae are the main menace to fish culture ponds. Ponds should be kept free from these aquatic weeds. Predatory animals can take shelter in the bushes, aquatic weeds and they can predate fishes from the pond. There are usually two methods of eradication of aquatic weeds like physical method (manual or mechanical) and chemical method. When aquatic vegetation is scanty and scattered or water body is small, weeds are often removed by handpicking or uprooting. Mechanical winches can also be used for cutting dense submerged weed. If the water body is large with heavy infestation are often cleared by applying chemical weedicides. Dead weeds generally calm down to rock bottom and decompose. Common weedicides, the weeds on which they affect their dose and method of application are given in Table-I.

Table I. Some doses and methods of herbicides to remove aquatic weeds.

\begin{tabular}{llll}
\hline Types of weeds & Herbicides & Doses & Method of application \\
\hline Aquatic grasses & Paraquat & $2 \mathrm{~kg} / \mathrm{ha}$ & Foliar spraying \\
\hline Aquatic grasses & Diuron & $4 \mathrm{~kg} / \mathrm{ha}$ & Root zone treatment \\
\hline All submerged weeds & Ammonia & $10-\mathrm{I} 5 \mathrm{ppm}$ & $\begin{array}{l}\text { Root zone treatment dispersal in } \\
\text { the water column }\end{array}$ \\
\hline Pistia & Ammonia & $\begin{array}{l}\text { I\% aqueous solution } \\
\text { with } 0.25 \% \text { wetting } \\
\text { agent }\end{array}$ & $\begin{array}{l}\text { Foliar spraying } \\
\end{array}$ \\
& & & \\
\hline
\end{tabular}

Source: Agropedia (2012)

Excess mud in the pond bottom can produce harmful gases. If the pond dike becomes broken then polluted water, unwanted animals can enter into the pond and fish can also escape from the pond. Embankments and sides should be repaired while removing the muck. Hard soil should be used for repairing the side slopes. If the pond bottom becomes bumpy then it creates problems during fish harvesting by netting. Bottom soil should be turned up for recovering the pond properly. Plough can help in releasing many obnoxious gases and in making the soil soft and bottom should be treated with lime So for the better pond environment, it is needed to remove the aquatic weeds and unwanted plants from the pond during March and April. Pond dike and bumpy bottom need to repair. If the hole is present in pond bottom and dike then it needs to be filled. Excess mud needs to remove from the pond bottom.

\subsubsection{Eradication of Predatory Fish}

Boal, shoal, gojar, taki, Chanda, kaki la, bele, chital, foil, etc. are the predatory fishes. If the predatory fishes remain in the pond then they eat fish seeds and fish feed. So before stocking of fish fry, all predatory fishes should be removed from the culture pond.

\section{I.2.I Procedures to Remove Predatory Fish from the Pond}

It is better to dry the pond for removing predatory fishes. From one side it is removed predatory fishes from the pond and another advantage, it is also removing harmful gases from the pond bottom. If pond drying is not possible then use small mesh net for frequent netting to remove predatory fishes. Bleaching powder (Calcium hypochlorite) can be applied at the rate of 25$30 \mathrm{ppm}$ for this purpose. The required quantity is dissolved in water and sprayed over the water surface. After 3-4 hours of spraying, the killed and distresses fishes are removed by repeated netting. Bleaching powder is effective only when it is fresh and 
kept in an airtight container. Toxicity lasts for 7-8 days. Fishes killed by this method are edible. The dose of bleaching powder can be reduced to half if it is applied 24 hours after the application of urea at the rate $100 \mathrm{~kg}$ ha- $\mathrm{I}$.

\subsection{Liming}

Liming is very important for the preparation of ponds before fish stocking. Lime makes pond water clean and also remove harmful gases from the bottom of the pond. Lime always balances the $\mathrm{pH}$ of the pond which makes the pond more productive. Application of lime depending upon the soil $\mathrm{pH}$ should be done. If the analysis of $\mathrm{pH}$ is not possible, a general rate of quick lime I-I.5/decimal after eradication of weed fishes should be applied as a preparatory dose. In subsequent operations, a monthly dose of $0.5 \mathrm{~kg} /$ decimal should be applied during the entire seed raising period to maintain the pH level. Liming in proper dose raises the soil and water $\mathrm{pH}$ to a desirable level to achieve the benefit of available nutrients for biological productivity. So it is necessary to liming the pond when it is needed.

\section{Precautions of Liming}

Some basic precautions should be followed during liming the pond. They are as follows-

- Lime should be sprinkled in windward direction to facilitate the slow melting of lime over a while and gradual mixing with water.

- Lime should be added to the water; water should not be mixed with lime

- For lime mixing and application, a plastic drum should not be used; it is better to use mud or cement pot or drum to mix the lime with water.

- Lime should be applied in a split-up dose and it is dangerous for fish if the amount for the year is applied as a single dose. Normally $25-30 \%$ of the total requirement is applied during pond preparation to dry bottom raked wet bottom soil. Remaining quantities of lime are applied in equal monthly installments and 7 days before the application of manures, especially phosphate fertilizers.

- Dry bottom of ponds is treated with powdered slaked or quick lime to disinfect and reduce the acidity of the soil. In the case of water-filled ponds if these two liming materials are used, they should be pre-dissolved to a liquid state in a container and after the exothermic reactions, dispersed over the water surface.

\subsection{Fertilization}

If optimum fertilization is done in the pond, then it makes the pond fertile. It will initiate natural food production which will reduce the application of supplementary feed and ultimately the production cost of fish production will be reduced. So after 5-7 days of liming 240gm urea/decimal and I I6gm TSP/decimal should be used to the pond. For this, the required amount of TSP should be mix with water into a drum to the whole night and then the next day required amount of urea should be mixed with TSP and water and should be sprinkled to the whole pond.

Cow dung should be applied 20-25 kg/decimal, after 5-7 days of application of lime and I5 days before the anticipated date of stocking by mixing with water and broadcasting all over the pond which increases the plankton production in due course for the stocked spawn (Baishya, 2018).

\subsection{Natural Food Testing}

After 5-7 days of fertilization, the natural food production in the pond should be tested. If the pond watercolor turns into green or brown then it should be understood that natural food started to produce. There are some methods of testing natural food in the pond.

\section{Secchi disc method}

The Secchi disc is a very simple tool that can be used to give a better estimate of turbidity. It is particularly useful in greencolored ponds to estimate plankton turbidity. This measurement is called the Secchi disc transparency. If the Secchi disc transparency is:

- Less than $40 \mathrm{~cm}$, there is too much plankton and your fish are in danger during the night when oxygen is not produced by photosynthesis and when too much oxygen is consumed by the respiration of this plankton;

- 40 to $60 \mathrm{~cm}$, the fish production will be the best;

- If transparency becomes over $60 \mathrm{~cm}$, there is too little plankton, and fish do not have enough natural food to eat.

\section{Hand method}

This is a very simple method which does not require any special equipment. Stretch one arm, and immerse it vertically into the water until your hand disappears and it should be done towards facing the sun. 
- If it is well below your elbow, plankton turbidity is very high;

- If it reaches to about your elbow, plankton turbidity is high;

- If it reaches well above your elbow, plankton turbidity is low the re-fertilization is needed for more natural food production.

\section{Towel-glass method}

- The pond water should be filtrate with a towel and taken into a clear glass.

- The glass should be examined with the help of sunlight.

- If very small-sized plankton is seen into the glass water then we have to understand that natural food is produced.

\subsection{Water Toxicity Test}

If the pond water becomes toxic then fish fry can be dying. So, it is needed to test the toxicity of the pond water before stocking of fish fry.

\section{Methods of Toxicity Test}

- Before I-2 days of fish stocking, a hapa should be set into the pond and preliminarily I0-I5 fish fry need to stock for demonstration.

- If all the fish fry dies then we have to understand that the pond water is toxic. In these cases, after 3-4 days fry should be stocked into the pond after proper treatment to reduce the toxicity of the water.

\section{Stocking Management}

\section{I Species Selection and Stocking Density Determination}

Species selection should be done by considering the upper layer, middle layer and bottom layer of the pond and fry need to stock into I:I:I ratio. By considering the pond model and water salinity the appropriate culture model should be selected by Table I and then fry should be stocked.

Table I. Different fish species and their stocking density

\begin{tabular}{|c|c|c|c|c|c|c|c|c|}
\hline \multirow[b]{2}{*}{$\begin{array}{c}\text { Species } \\
\text { (Scientific name) }\end{array}$} & \multirow{2}{*}{$\begin{array}{l}\text { Size } \\
\text { (Inch) }\end{array}$} & \multicolumn{7}{|c|}{ Stocking density/decimal } \\
\hline & & $\begin{array}{c}\text { Mod- } \\
\text { I }\end{array}$ & $\begin{array}{c}\text { Mod- } \\
2\end{array}$ & $\begin{array}{c}\text { Mod- } \\
3\end{array}$ & $\begin{array}{c}\text { Mod- } \\
4\end{array}$ & $\begin{array}{c}\text { Mod- } \\
5\end{array}$ & Mod-6 & Mod-7 \\
\hline Gibelion catla & $4-6$ & $5-8$ & - & $5-8$ & - & - & 10 & 13 \\
\hline Hypophthalmichthys molitrix & $3-5$ & $15-18$ & - & $\mathrm{IO}-\mathrm{I} 2$ & - & - & - & - \\
\hline $\begin{array}{c}\text { Labeo rohita/ Aristichthsy } \\
\text { nobilis }\end{array}$ & $6-8$ & $20-25$ & 20 & - & - & - & 10 & I3 \\
\hline Barbonymus gonionotus & $2-3$ & - & - & $15-20$ & 20 & - & - & - \\
\hline $\begin{array}{c}\text { Cirrhinus mrigala/ Cyprinus } \\
\text { carpio } \\
\end{array}$ & $6-8 / 3-4$ & $20-25$ & - & $\mathrm{I} 5-20$ & - & - & 10 & I4 \\
\hline Tilapia mossumbicus & $3-4$ & - & 80 & - & 80 & - & 30 & 40 \\
\hline Pangasius hypothalmus & $6-8$ & - & - & - & - & 200 & - & - \\
\hline Amblypharyngodon mola & - & - & 100 & - & - & - & - & - \\
\hline Total & & $60-76$ & 200 & $45-60$ & 100 & 200 & 60 & 80 \\
\hline
\end{tabular}

Model- I, 2, 6 and 7: The pond where 3 feet water remains available all the year-round.

Model-3: Only for seasonal pond

Model-4: Coastal region saline water pond

Model-5: Those who have the ability to by commercial feed tor fish culture

\subsection{Quality Fish Seed Selection}

The seed which is active, healthy in appearance, uniform in size, with potential for high survival, better growth, less or no disease usually fit this definition of good quality seed, irrespective of the species. According to Mohan (2007) there are several factors that could contribute to the quality of seed. Some of the important factors which are perceived to have a significant impact on quality include: 
- Brood-stock

- Husbandry (hatchery and nursery)

- Seed movements and availability (transport, holding, and distribution, trans-boundary movements)

- Pathogens and diseases (important parasitic, bacterial, fungal and viral diseases)

For better fish production fish seed need to collect from a reliable hatchery or other sources. Common features of good quality seeds are-

- The body should be bright, shiny and slimy

- Spontaneous movement into the water

- Always try to move against the current

- Fry quickly shakes the head when pressing in the tail

\subsection{Fry Transportation}

It is needed to transport fish fry with great care to reduce the fry mortality rate. It is needed to know whether fish fry is conditioning for sale. During fry transportation, the following guidelines should be followed-

- It is better to transport fry of one species in a bag rather than different species

- Transportation early in the morning is better (Cool Hour).

- The water used in transportation should be cool and clean.

- The number of fish seeds per transportation unit should be maintained, over number may lead to the death of fishes.

- Oxygen packing is the best method of transportation.

- Anesthetics can be used while transportation to minimize the metabolic activities of the fish seeds. Thereby, excretion of the nitrogenous compounds can be avoided.

- Care should be taken so that no direct sunlight falls in the packing bags during transportation.

- The seed packing bags should be covered with wet gunny bags. So that, the temperature of the seed packing bags will be maintained low.

- If the transporting distance is long, glucose powder can be added to the seed packing bags.

- To remove the toxic ammonia from the media to safeguard the seedlings from the mortality, the absorbent is added which can reduce $50 \%$ of ammonia for 24 hours transportation.

\subsection{Fry Acclimatization}

When the pond is stocked with seeds without proper acclimation, the fish seed may die due to stress and, actual stocking density would be less than expected would lead to lower production. Acclimation aims is to minimize stress to fish seed through a gradual change in salinity, temperature, and $\mathrm{pH}$ of transport water to that of pond water. For this, before 24 hours of seed transportation, they have put into a hapa without giving any feed. Sometimes water splashes should be given to evacuating the belly of fish seed. By following this process easily fish seed can be transported to a longer distance without less seed mortality.

\subsection{Fry Conditioning and Stocking}

Fish seed should stock on sunny days either in the morning or in the evening when the water temperature becomes low. The fish seed must be conditioning before stocking to the pond. For this, the following steps should be followed to stock fish seed-

- The transportation bags should be kept in the pond water for an hour before stocking so that the water temperature between transportation bags and pond becomes balance.

- Then pond water should be entered into the transportation bag slowly and recline the bags towards the pond so that fish seed willingly enters into the pond.

\section{Post-Management Practice}

Post stocking management in the fish culture at the very beginning depicts the importance of providing nutrition to the cultured species along with feeding management practices. Secondly the application of lime and fertilizers in regular installments at periodic intervals for the production of natural fish food organisms is relished upon by the cultured species. While carrying out these management practices, the environment where the fish lives must be made congenial for its healthy growth, and thus emphasis should be given to water quality management. After all the necessary technical interventions that in made during post stocking management practices periodical monitoring of the fish pond is of utmost importance in terms of whether the supplementary feed is being utilized properly and also ascertain the effect of lime and fertilizers after it applies for the maintenance of optimum water quality parameters required for the good and healthy growth of fishes. If periodical monitoring is 
done any deviations from the optimum can be worked upon and made favorable for the cultured fishes which otherwise can affect the growth of fishes (Baishya, 2018).

\section{I Liming}

Liming is a universal treatment for pond even after stocking of fish seed liming is necessary for increasing the productivity in the pond. Liming improves the cultural environment for fish. It also encourages natural food production in the pond. For this $250-$ $300 \mathrm{gm}$ limestone/decimal should be applied by mixing with water into the pond every I.5-2 months later.

\subsection{Fertilization}

Pond fertilization for herbivorous fish culture is a must to increase productivity at various levels. Organic and inorganic fertilizers are used the world over and a combination of both have been found more suitable and economic for carp fish culture. Fertilization in the pond water is needed for continuous natural food production. After stocking of fish seed $250 \mathrm{gm}$ urea and I30gm TSP per decimal should be applied every I5 days later but a combination of organic manure and inorganic fertilizers has been considered as the most effective way to increase primary productivity of carp culture ponds. Cow-dung, plant material, rice bran, wheat bran, molasses, cottonseed meal, tea seed cake, oilseed cakes, etc. can be used as organic fertilizer. Cow-dung can be used in a $10-12 \mathrm{~kg} /$ decimal rate every month later. Before fertilization, the natural food condition in the pond should be tested. If there is enough natural food in the pond then there is no need for fertilization.

\subsection{Supplementary Feed}

The supplementary feed should be used for rapid fish growth. Supplementary feed need not use for other fishes without pangas, rice bran is enough for them for proper growth. For better production of pangas, supplementary feed should be used. Otherwise the expected outcome will not come. The supplementary feed should be used to the fish according to Table 02

Table 2. Supplementary feeding rate of fish

\begin{tabular}{ccc}
\hline Month (After stocking) & \multicolumn{2}{c}{ Daily feeding rate (\% body weight) } \\
\cline { 2 - 3 } & For catfish & For carp fish \\
\hline$I^{\text {st }}$ month & $22 \%$ & $7 \%$ \\
\hline $2^{\text {nd }}$ month & $15 \%$ & $6 \%$ \\
\hline From $3^{\text {rd }}$ to until harvest & $7 \%$ & $4 \%$ \\
\hline
\end{tabular}

The feed is better utilized if the fish are fed twice daily - morning and evening. Every day the feed which is given to fish should be divided into two portions. One portion should be given in the morning (from 8-I0 A.M.) and another portion should be given in the late afternoon (from 3-5 P.M). The following guidelines should be followed during application of supplementary feed to the pond-

- If the feed is given more than the optimum level then the uneaten feed will decompose into the pond and will make the water polluted.

- The feeding rate should make half during the winter season than in the summer season.

- If there is Barbonymus gonionotus (Thai sarputi) into the pond then green grass and vegetable leaves should be cut into slices and given on the bamboo frame

- If mustard oil cake and rice bran are used as supplementary feed then both mustard oil cake and rice bran should be mixed and made into dough. Then the feed is kept in a bamboo tray and placed at a particular depth of the pond. The feeding tray is tied to a pole fixed on the embankment with the help of a rope to avoid displacement of the tray. For I ha of a fish pond, IO to I5 trays are sufficient. Depending upon the depth of the pond, the feeding trays are adjusted to different depths by shortening or lengthening the rope.

- During rain, the feeding rate should be reduced

\subsection{Fish Health Test}

The health of fish needs to be checked regularly by periodic netting at least once in two months. Healthy fish grow well and feed voraciously. If it is observed that the feed provided is not being consumed, either the fish is suffering from some disease or the water quality is deteriorated. A check on the water quality and hygiene of the pond and the health of the fish is necessary to take remedial measures. 


\subsection{Fish Harvesting}

Normally in stocking ponds fish is allowed to grow for 12 months and during this period Catla attains a weight of 800 gm - I kg; Rohu 600 - 800 gm; Mrigal 400 - 600 gm; Silver carp I.0 - I.2 kg; Grass carp I.0 - I.5 kg and Common carp 800 gm $\mathrm{I} .0 \mathrm{~kg}$. But if fish culture condition is favorable then after I.5-2 months some fish will be consumable sizes. Larger fish can be harvested for home consumption or for selling into the market to fulfill the demand. During fish harvesting, the following points should be taken into consideration-

- Fish weight: Fish should be table size

- Market price: During any festival the price become high

- Risks: Flood, drought, winter, pouching are the risks for fish culture

- Seed Availability: After partial harvesting for restocking of seeds into the pond

During fish harvesting, two methods should be followed by the fish farmers. Like:

- Partial harvesting and restocking, and

- Complete harvesting

\subsection{Partial Harvesting and Restocking}

By partial harvesting and restocking of fish seed, fish production can be increased. In the case of partial harvesting, I5-20\% more fry should be stocked than the number of species to be caught.

\subsubsection{Complete Harvesting}

Complete harvesting can be done by pond drying or by surrounding netting. Complete harvesting is done at the end of the desired period. The pond makes ready again for fish culture after the complete harvesting of fish.

\section{Some guidelines during fish harvesting}

- The dry and clean net should be used for harvesting; this will ensure less probability of spread diseases

- During partial harvesting undersize fishes should be immediately released into the water

- During harvesting, fish should not be stressed; it will make the fish tired and encourage decomposition.

\subsubsection{Marketing}

Fish should be marketed early in the morning or local market time. Fish should be marketed after properly cleaning to reduce the chance of decomposition. Live fishes have high market demand and prices. So, if it is possible to live fish should be marketed for getting better prices and profit.

\section{Conclusion}

The fisheries sector is the most emerging and potential sector in Bangladesh. It has a great contribution to livelihood development and nutrition for rural people of Bangladesh. But in some cases, the immense potential of this sector has remained largely unutilized due to ignorance of such potential resources and lack of technical knowledge in this respect in Bangladesh. Nevertheless, proper aquaculture system design, good stocking, and water quality management are essential to successful and quality fish production. Consequently, maintaining a good culture environment through the use of proper management practices will reduce the risk of disease and increase production, fish quality, and marketability. Therefore, it is essential to implement and follow good aquaculture management practices to ensure quality and quantity yield. Aquaculture business is viable in Bangladesh from all indications but needs more efforts from the both public and government to increase its local production to bridge the gap between the fish demand and supply in the country.

\section{References}

Agropedia. (2012). Retrieved from http://agropedia.iitk.ac.in/content/removal-aquatic-weeds-fish-rearing-ponds/ Baishya, S. (2018). Pre stocking and post stocking management practices in carp culture. APART (CoF, AAU). DoF. (2018). Yearbook of Fisheries Statistics of Bangladesh, 2017-I8. Fisheries Resources Survey System (FRSS), Department of Fisheries. Bangladesh: Ministry of Fisheries, Volume 35: p. 129

FAO. (2018). Fisheries and Aquaculture Department. Retrieved from http://www.fao.org.

Mohan, C.V. (2007). Seed quality in freshwater fish production. pp. 499-5I7. In: M.G. Bondad-Reantaso (ed.). Assessment of freshwater fish seed resources for sustainable aquaculture. FAO Fisheries Technical Paper. No. 50I. Rome, FAO. $628 \mathrm{p}$. 
Sunny, A.R., Masum, K.M., Islam, N., Rahman, M., Rahman, A., Islam, J., Rahman,S., Ahmed, K.J., Prodhan, S.H. (2020a). Analyzing livelihood sustainability of climate-vulnerable fishers: Insight from Bangladesh. Journal of Aquaculture Research and Development, II(6).

Sunny, A.R., Sazzad, S.A., Datta, G.C., Sarker, A.K., Ashrafuzzaman, M., Prodhan, S.H. (2020b). Assessing Impacts of COVID-I9 on Aquatic Food System and Small-Scale Fisheries in Bangladesh.

The World Bank. (2018). Retrieved from https://data.worldbank.org/indicator/SP.POP.TOTL?locations=BD/

Zahura, I., \& Islam, M.S. (2017). ECOFISH-BD. Dhaka, Bangladesh: WorldFish, Manual. pp. 20

\section{Copyrights}

Copyright for this article is retained by the author(s), with first publication rights granted to the journal. This is an open-access article distributed under the terms and conditions of the Creative Commons Attribution license (http://creativecommons.org/licenses/by/4.0/). 